\title{
Small cell carcinoma in ulcerative colitis - new treatment option: a case report
}

\author{
Christoforos Kosmidiš, Christoforos Efthimiadis, Georgios Anthimidis, Kalliopi Vasiliadou, loanna Tzeveleki, \\ Panagiotis Fotiadis, Georgios Basdanis
}

\begin{abstract}
Background: The most common type of carcinoma associated with ulcerative colitis (UC) is adenocarcinoma. We present a case of primary rectal small cell carcinoma in a patient with a history of UC.

Methods: A 34-year-old male diagnosed with UC for 10 years was not consistent with the usual annual follow-up and presented with mucoid-bloody diarrhea. Colonoscopy revealed a rectal mass $2 \mathrm{~cm}$ distant from the anal verge. The patient underwent a total proctocolectomy with preservation of the anal sphincters, construction of an ileal reservoir, anastomosis of the reservoir to the anus (J configuration) and protective loop ileostomy.

Results: Histological examination showed undifferentiated small cell carcinoma.

Conclusions: This is the first case of small cell carcinoma in a background of UC reported to be treated surgically and the patient and has no reccurence 18 months postoperatively.
\end{abstract}

\section{Background}

Primary small cell carcinoma (SCC) of the colon and the rectum is very rare, with an incidence of less than $0,2 \%$ of all colorectal cancers [1]. The most common histological type of carcinoma associated with ulcerative colitis is adenocarcinoma [2]. We present a case of primary rectal small cell carcinoma in a patient with a history of ulcerative colitis, which is the fifth case reported and the first treated surgically.

\section{Methods}

Case presentation

A 34-year-old male diagnosed with ulcerative colitis for 10 years presented with mucoid-bloody diarrhea and none extraintestinal manifestation. His haemoglobin was $10,6 \mathrm{gr} / \mathrm{dl}$. The patient had been prescribed methylprednisolone 24 gr daily during the last years, but he was not consistent with the usual annual follow-up. A colonoscopy was immediately performed and revealed a rectal mass $2 \mathrm{~cm}$ distant from the anal verge.. Biopsy results of the colonoscopy showed an undifferentiated small cell carcinoma positive to Thyroid transcription

\footnotetext{
* Correspondence: dr.ckosmidis@gmail.com
Department of Surgery, Interbalkan European Medical Center, Thessaloniki,

* Correspondence: dr.ckosmidis@gmail.com
Department of Surgery, Interbalkan European Medical Center, Thessaloniki, Greece
}

(c) 2010 Kosmidis et al; licensee BioMed Central Ltd. This is an Open Access article distributed under the terms of the Creative Commons Attribution License (http://creativecommons.org/licenses/by/2.0), which permits unrestricted use, distribution, and reproduction in any medium, provided the original work is properly cited.

\section{Results}

Histological examination showed small oval and round undifferentiated cells with oval hyperchromatic nuclei and scanty cytoplasm, as well as findings suggestive of ulcerative colitis (Figures 3, 4 and 5). Immunohistochemically the tumor was positive to synaptophysin, neuron specific enolase (NSE), CD56 and TTF1 (Figures $6,7,8$ and 9). Based on these findings, the diagnosis was undifferentiated small cell carcinoma. The postoperative period was uneventful and the patient was discharged on the twelfth postoperative day. He received adjuvant chemotherapy with Carboplatin $400 \mathrm{mg} / \mathrm{m}^{2}$ and Etoposide (Vepesid) $250 \mathrm{mg} / \mathrm{m}^{2}$ and radiotherapy.

factor-1 (TTF-1). Subsequently a primary location in the (MRI) scan confirmed that finding by demonstrating a rectal tumor extending between $2 \mathrm{~cm}$ proximally to the anal verge and $7 \mathrm{~cm}$ in the rectal canal, and enlarged adjacent lymph nodes. Abdominal, chest and brain compatient underwent a total proctocolectomy with preservation of the anal sphincters, construction of an ileal reservoir, anastomosis of the reservoir to the anus (J configuration) and protective loop ileostomy (Figures 1 and 2). 


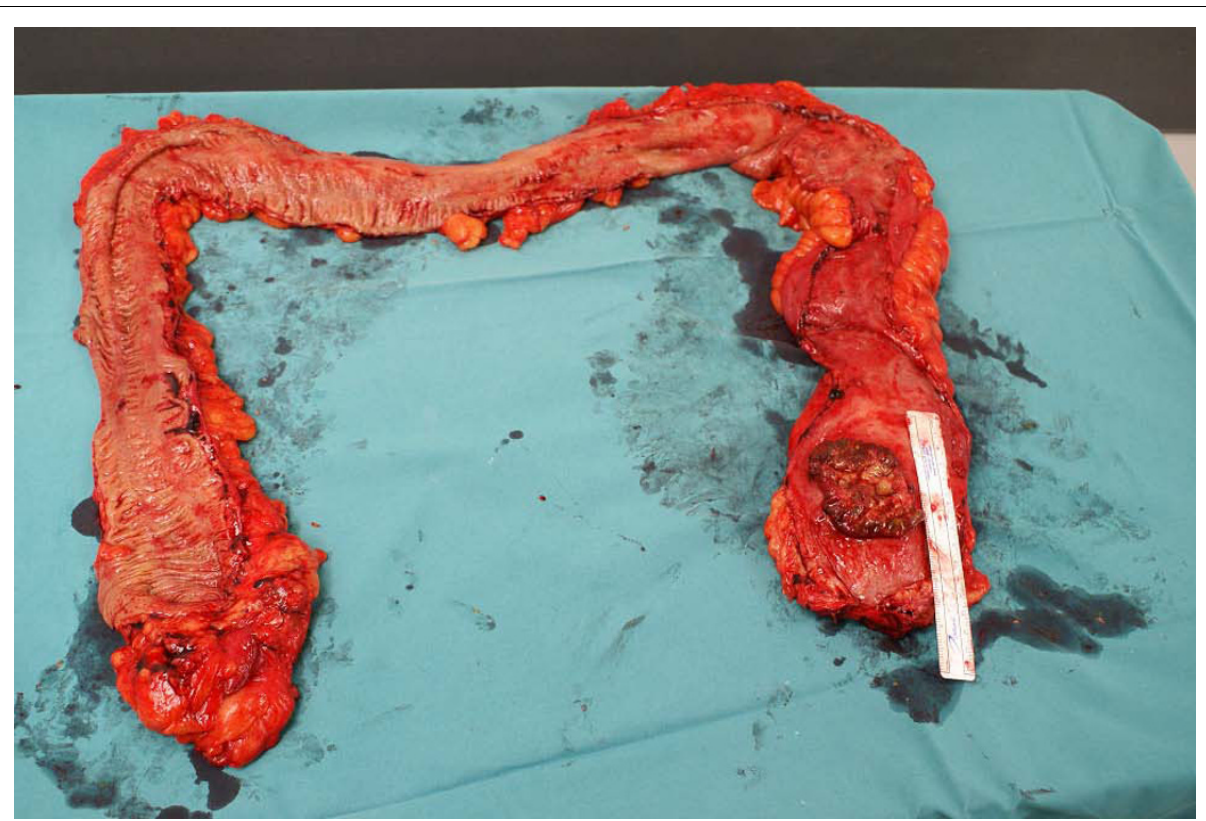

Figure 1 Total proctocolectomy specimen with ulcerative colitis and small cell carcinoma in the inferior part of the rectum.

Eighteen months post-surgery there is no sign of recurrence.

\section{Discussion}

The risk of colorectal cancer for any patient with ulcerative colitis is known to be elevated, and is estimated to be $2 \%$ after 10 years, $8 \%$ after 20 years and $18 \%$ after 30 years of disease. Malignancy risk factors include extent and duration of ulcerative colitis, primary sclerosing cholangitis, a family history of sporadic colorectal cancer, severity of histologic bowel inflammation, and in some studies, young age at onset of colitis. The exact mechanism for carcinogenesis is partly unknown; in some cases it can be explained by the more widespread use of maintenance therapy and surveillance colonoscopy [3]. In our case the patient had had a history of

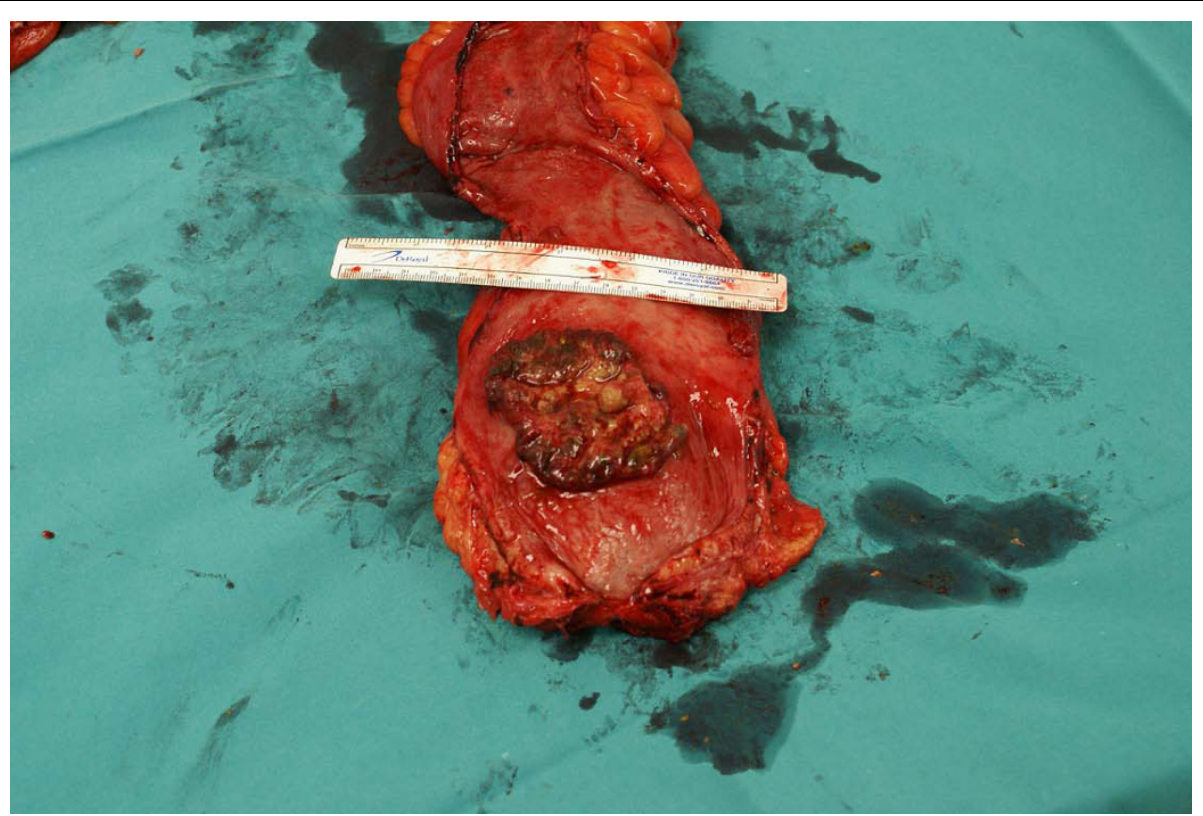

Figure 2 Magnification of the small cell carcinoma in the inferior part of the rectum. 


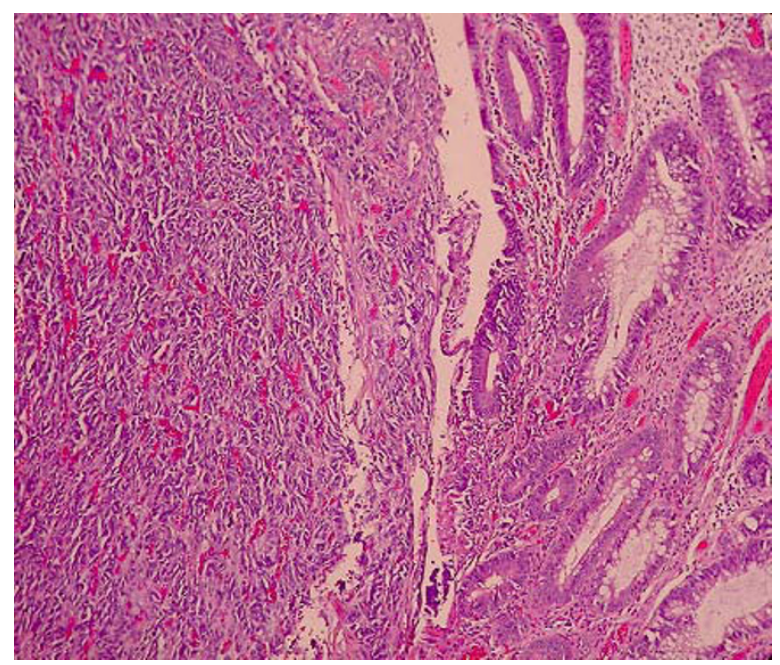

Figure 3 Small cell carcinoma with invasion of the mucosa $(\mathrm{H}+\mathrm{E} \times 100)$.

ulcerative colitis for the last 10 years, specifically from the age of 24 years old, a condition characterized by a severe bowel inflammation.

The most common histological type of carcinoma associated with ulcerative colitis is adenocarcinoma [2]. We report this case because of the fact that SCC, instead of adenocarcinoma, on a background of ulcerative colitis is a very rare neoplasm [4]. The same factors that lead to adenocarcinoma in the background of ulcerative colitis, are also responsible for SCC, as there is the strong evidence that the tumorigenesis of all histologic types of colorectal cancer arises from a pluripotential stem cell in the mucosa of the large intestine [5]. Thus there are also other histological types of tumors arising in the background of ulcerative colitis e.g. lymphoma, lymphosarcoma, carcinoid, as the long-standing

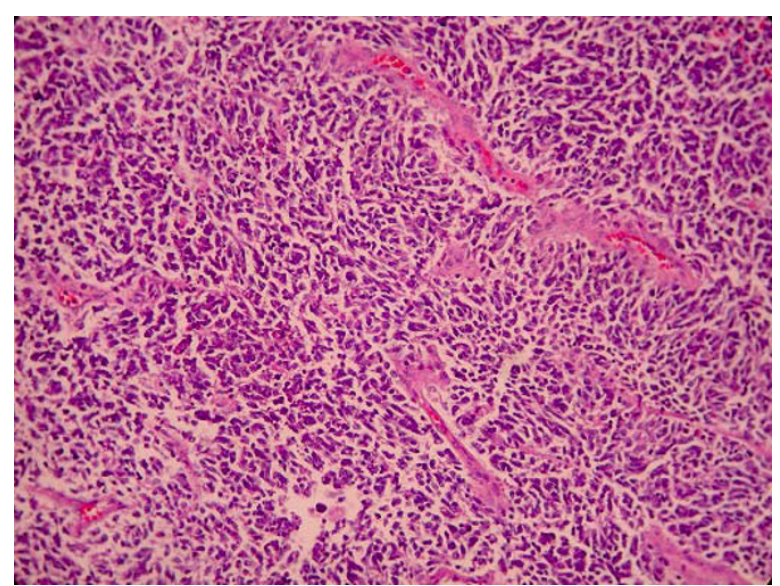

Figure 4 Small cell carcinoma in deeper invasion $(H+E \times 200)$.

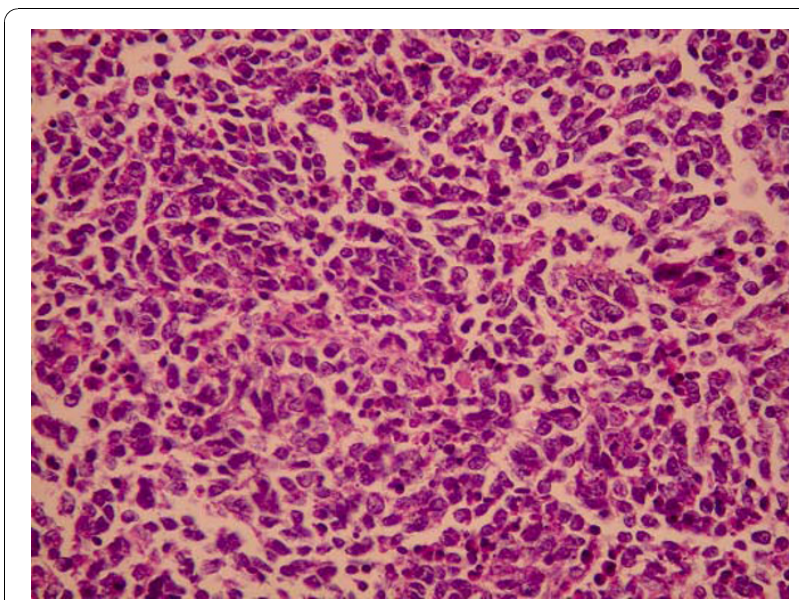

Figure 5 Small cell carcinoma in deeper invasion $(\mathrm{H}+\mathrm{E} \times 400)$.

history of inflammatory bowel diseases has been proved to be responsible for carcinogenesis [6]. Still, as far as we could elicit from the literature our case is just the fifth report of SCC in ulcerative colitis [7-10], while the rarity of the histologic type of SCC in ulcerative colitis be of great interest.

Colorectal SCC is characterized by three histological types: the undifferentiated small cell carcinoma, the neuroendocrine carcinoma and the stem cell carcinoma. Each of these subtypes has different histological characteristics which reveal the differentiation of the tumor. The most undifferentiated subtype consists of small tumor cells and scanty cytoplasm. The neuroendocrine carcinoma is characterized by larger tumor cells and abundant cytoplasm. The third type is a transitional histological type between the other two types [4]. In our case, the small cell carcinoma was of the undifferentiated type.

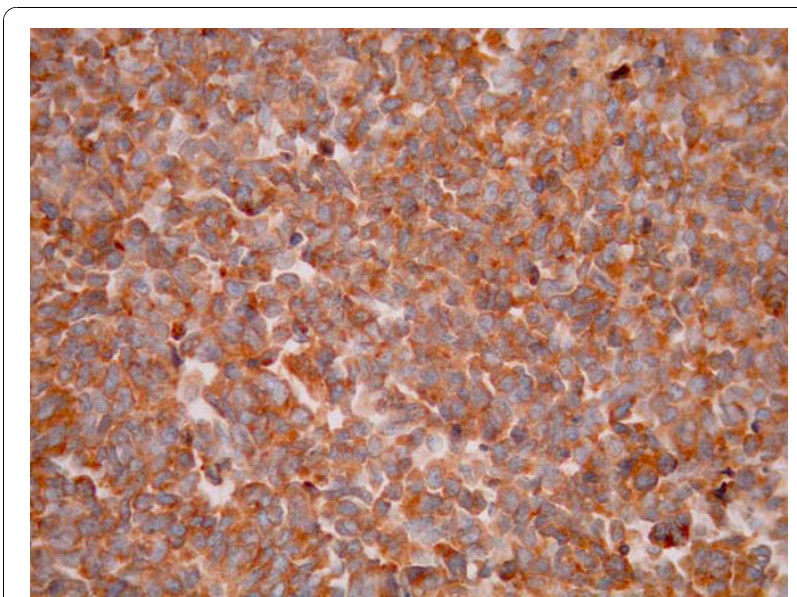

Figure 6 Tumor cells are positive for Synaptophysin immunostain $(\times 400)$. 


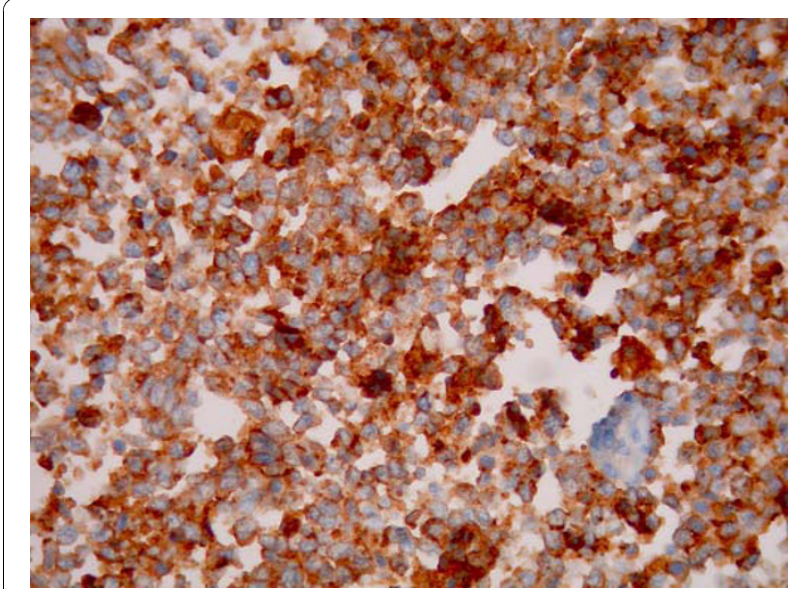

Figure 7 Tumor cells are positive for CD56 immunostain $(\times 400)$.

The diagnosis of a small cell carcinoma can not be based only on the microscopical appearance, as it is often difficult to make a distinction among other "small blue cell tumors" e.g. lymphomas, melanomas, cloacogenic carcinomas [9]. For that reason the diagnosis must be confirmed immunohistochemically, as almost all types of SCC react positive to synaptophysin, chromogranin, cytokeratine and neuron specific enolase (NSE) [4]. A positive reaction to synaptophysin is the most reliable marker. However, a tumor must be positive to at least two of the markers to have a standard diagnosis [4]. In our case the tumor was positive to synaptophysin and NSE, which confirmed the diagnosis. There is a positive correlation between high differentiation of the tumor and the positivity of the above markers [4]. Nevertheless, even undifferentiated small cell carcinomas react positive to these markers, as in our case.

Primary SCC can be found in different locations such as the lung, the skin, the kidney, the thymus, the

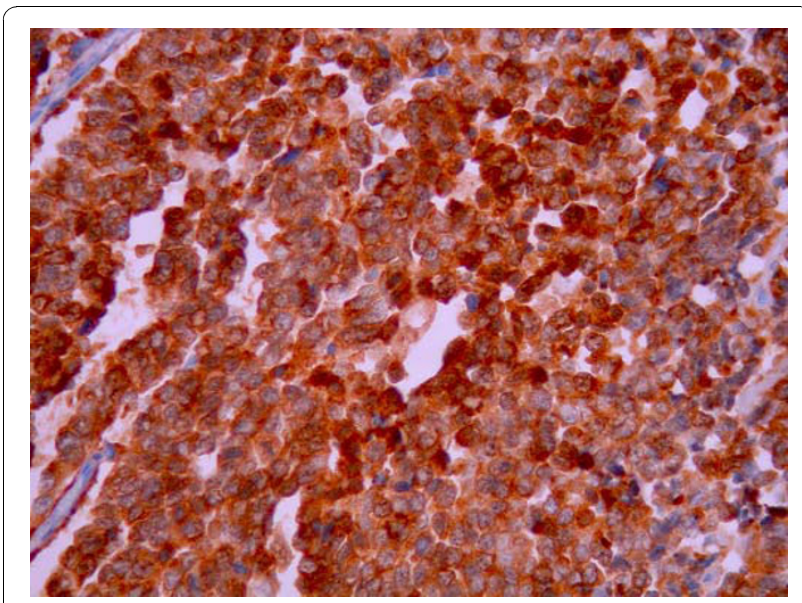

Figure 8 Tumor cells are positive for NSE $(\times 400)$.

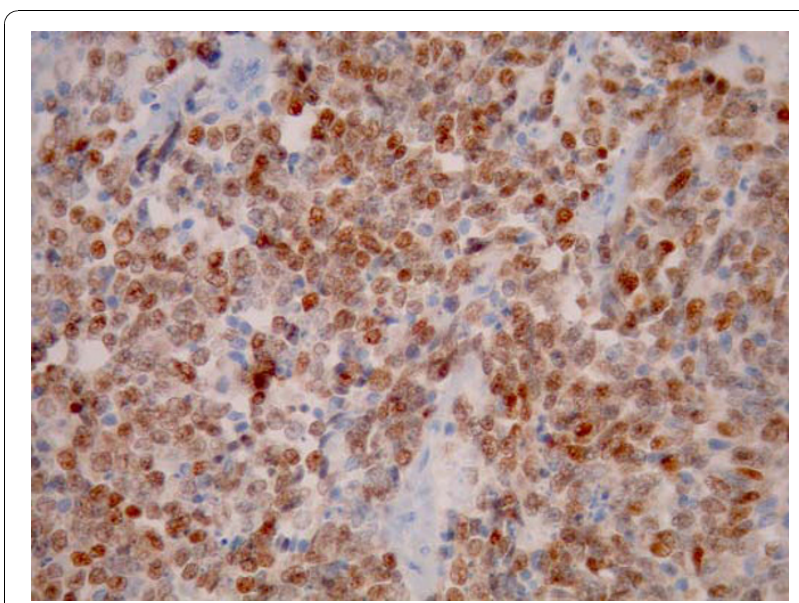

Figure 9 Nuclear positivity for TTF1 immunostain $(\times 400)$.

pancreas, the uterus etc [11]. The most common gastrointestinal location is the rectum, followed by the cecum and the sigmoid whereas the descending colon has never been reported as a location [4]. In our case tumor was also found in the rectum.

Small cell carcinomas are very aggressive, specifically when compared with adenocarcinomas of the same stage [4]. The 6-month survival rate is $58 \%$ and a 5 -year survival rate is $6 \%$ [10]. Seventy to eighty percent of patients have already liver metastases and lymph node involvement at presentation and the prognosis is very poor [12]. For these cases multidrug chemotherapy and radiation therapy are strongly suggested [13]. Nevertheless, radical surgery offers a more favorable prognosis to some patients at an early stage, when no distant metastases are present [13]. In our case the patient had no metastases at the time of presentation, so a radical surgery was performed. Intraoperative exploration revealed no metastasis and the patient underwent a total proctocolectomy with preservation of the anal sphincters, construction of an ileal reservoir, anastomosis of the reservoir to the anus ( $J$ configuration) and protective loop ileostomy. He received adjuvant chemotherapy and radiotherapy and has no recurrence 18 months postsurgery.

\section{Conclusions}

This is the first case of small cell carcinoma in a background of UC reported to be treated surgically and the patient and has no reccurence 18 months postoperatively.

\section{Consent}

Written informed consent was obtained from the patient for publication of this case report and accompanying images. A copy of the written consent is available for review by the Editor-in-Chief of this journal. 


\section{List of abbreviations}

(SCC): Primary small cell carcinoma; (TTF-1): Thyroid transcription factor-1; (MRI): Magnetic resonance imaging; (CT)computerized tomography; (NSE): neuron specific enolase.

\section{Authors' contributions}

All authors contributed the same.

\section{Competing interests}

The authors declare that they have no competing interests.

Received: 29 June 2010 Accepted: 18 November 2010

Published: 18 November 2010

\section{References}

1. Mills SE, Allen MS, Cohen AR: Small-cell undifferentiated carcinoma of the colon. A clinicopathological study of five cases and their association with colonic adenomas. The American journal of surgical pathology 1983, 7(7):643-51.

2. Riddel RH, Goldman H, Ransohoff DF, Appelman HD, Fenoglio CM, Haggitt RC, et al: Dysplasia in inflammatory bowel disease: standardized classification with provisional clinical applications. Human pathology 1983, 14(11):931-68.

3. Lakatos PL, Lakatos L: Risk for colocteral cancer in ulcerative colitis: Changes, causes and management strategies. Journal of Gastroenterology 2008, 14(25):3937-3947.

4. Gaffey MJ, Mills SE, Lack EE: Neuroendocrine carcinoma of the colon and rectum. A clinicopathologic, ultrastructural and immunohistochemical study of 24 cases. The American journal of surgical pathology 1990, 14(11):1010-23.

5. Nugent FW, Haggitt RC, Gilpin PA: Cancer surveillance in ulcerative colitis. Gastroenterology 1991, 100(5 Pt 1):1241-8.

6. Bashiti HO, Kraus FT: Histiocytic lymphoma in chronic ulcerative colitis. Cancer 1980, 46(7):1695-1700

7. Harikumar R, Thomas N, Mathew T: Small cell carcinoma occurring in a case of ulcerative colitis. Tropical gastroenterology: official journal of the Digestive Diseases Foundation 2008, 29(4):224-6.

8. Rubin A, Pandya PP: Small cell neuroendocrine carcinoma of the rectum associated with chronic ulcerative colitis. Histopathology 1990, 16(1):95-7.

9. Wick MR, Weatherby RP, Weiland LH: Small cell neuroendocrine carcinoma of the colon and rectum: clinical, histologic and ultrastructural study and immunohistochemical comparison with cloacogenic carcinoma. Human pathology 1987, 18(1):9-21.

10. Yaziji $H$, Broghamer W: Primary small cell undifferentiated carcinoma of the rectum associated with ulcerative colitis. Southern Medical Journal 1996, 89(9)-921.

11. Chejfec G, Falkmer S, Askensten U, Grimelius L, Gould VE: Neuroendocrine tumors of the gastrointestinal tract. Pathology, research and practice 1988, 183(2):143-54

12. Palvio DH, Sorensen FB, K M: Stem cell carcinoma of the colon and rectum. Report of two cases and review of the literature. Diseases of the colon and rectum 1985, 28(6):440-5.

13. Okuyama T, Korenaga D, Tamura S, Yao T, Maekawa S, Watanabe A, Ikeda T, Sugimachi K: The effectiveness of chemotherapy with cisplatin and 5fluorouracil for recurrent small cell neuroendocrine carcinoma of the rectum: report of a case. Surgery today 1999, 29(2):165-9.

doi:10.1186/1477-7819-8-100

Cite this article as: Kosmidis et al:: Small cell carcinoma in ulcerative colitis - new treatment option: a case report. World Journal of Surgical Oncology 2010 8:100

\section{Submit your next manuscript to BioMed Central and take full advantage of:}

- Convenient online submission

- Thorough peer review

- No space constraints or color figure charges

- Immediate publication on acceptance

- Inclusion in PubMed, CAS, Scopus and Google Scholar

- Research which is freely available for redistribution 